\title{
Annual
}

\section{Site Environmental Report}

\section{Calendar Year 2010}

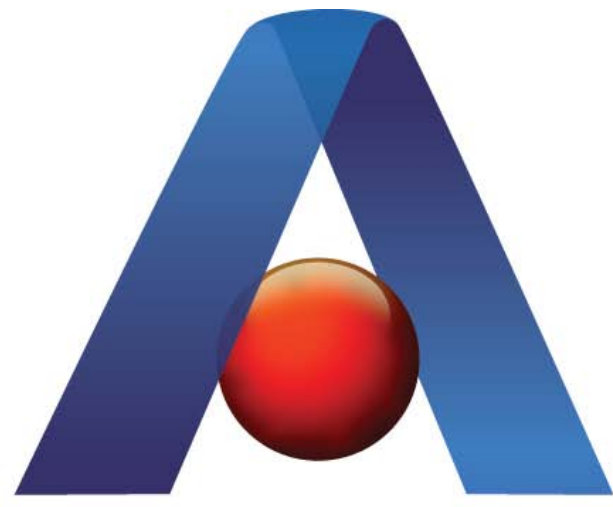

тне Ames Laboratory Creating Materials \& Energy Solutions

\section{U.S. DEPARTMENT OF ENERGY}

\author{
Iowa State University
}

Ames, lowa 50011-3400

Prepared for the

U.S. Department of Energy

Under Contract No. DE-AC02-07CH11358 
Feedback Form

2.0 INTRODUCTION

2.1 Site Description

2.2 Organization and Administration 5

Figure 2.2-1 Organizational Chart 5

2.3 Mission 6

2.4 Purpose of Site Environmental Report 6

3.0 COMPLIANCE SUMMARY $\quad 7$

3.1 Calendar Year 2010 Compliance Status 7

3.2 Comprehensive Environmental Response, Compensation 7 and Liability Act (CERCLA)

3.3 Resource Conservation and Recovery Act (RCRA) 7

Figure 3.3-1 RCRA Hazardous Waste Volumes 7

3.4 Federal Facilities Compliance Act (FFCA) 8

3.5 National Environmental Policy Act (NEPA) 9

3.6 Clean Air Act (CAA) and National Emissions Standards for 9 Hazardous Air Pollutants (NESHAPS)

3.7 Clean Water Act (CWA)

3.8 Safe Drinking Water Act (SDWA) 10

Table 3.8-1 Drinking Fountain Analysis 10

3.9 Superfund Amendments and Reauthorization Act (SARA)Title III 10 and lowa Administrative Code (IAC), Rule 567, Chapter 131, Spill Response

Table 3.9-1 Status of EPCRA Reporting

3.10 Toxic Substances Control Act (TSCA) 11

Figure 3.10-1 Asbestos Volumes 12

Figure 3.10-2 PCB Volumes 12

3.11 Federal Insecticides, Fungicide and Rodenticide Act (FIFRA) 13

3.12 Endangered Species Act (ESA) 13

3.13 National Historic Preservation Act (NHPA) 13

3.14 Migratory Bird Treaty Act $\quad 13$

3.15 Executive Order 11988, "Floodplain Management" 13

3.16 Executive Order 11990, "Protection of Wetlands" 14

3.17 Summary of Permits $\quad 14$

Table 3.17-1 DOE RCRA Generator Identification Numbers 14

Table 3.17-2 Ames Laboratory Air Emission Sources 15

$\begin{array}{lr}\text { 4.0 ENVIRONMENTAL PROGRAM } & 16\end{array}$

4.1 Environmental Management System 16

4.1.1 EMS Effectiveness 16

4.2 Pollution Awareness, Waste Minimization and Recycling Programs 16

$\begin{array}{ll}\text { 4.3 Performance Measures } & 17\end{array}$ 
5.1 DOE Order 5400.5, "Radiation Protection of the Public 18 and the Environment"

5.2 DOE Order 435.1, "Radioactive Waste Management" 18

5.3 Property Release 18

5.4 Radiation Emissions and Doses 18

5.5 Unplanned Releases 18

5.6 Environmental Monitoring 19

5.7 Areas of Concern 19

5.7.1 Chemical Disposal Site (CDS) 19

Table 5.7-1 CDS Groundwater Analysis 20

5.7.2 Inactive Waste Sites (IWS) 21

6.0 ENVIRONMENTAL NON-RADIOLOGICAL PROGRAM 22

6.1 Emissions Monitoring $\quad 22$

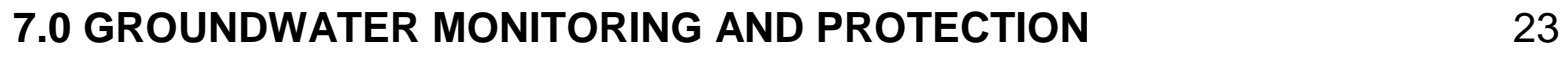

$\begin{array}{ll}\text { 8.0 QUALITY ASSURANCE PROGRAMS } & 24\end{array}$

$\begin{array}{ll}\text { 9.0 REFERENCES } & 25\end{array}$

$\begin{array}{ll}10.0 \text { LIST OF ACRONYMS } & 27\end{array}$

$\begin{array}{ll}\text { 11.0 REPORT DISTRIBUTION } & 30\end{array}$

APPENDIX A (Chemical Disposal Site (CDS) Correspondences) 35

1) Letter to IDPH requesting release of the CDS, September 30, 1998.

2) Letter from IDPH granting "unrestricted" release of the CDS, October 15, 1998.

3) Letter from IDPH to Edward J. Stanek, II, Ph.D., status of CDS, October 16, 1998.

4) Letter from ISU to DOE-Ames Group, October 22, 1998.

5) Letter from IDNR to ISU-EH\&S, groundwater monitoring status, October 8, 2008.

APPENDIX B (Air Permit Correspondences)

1) U.S. Department of Energy Air Emissions Annual Report, Calendar Year 2010.

APPENDIX C (Inactive Waste Site Correspondences)

1) Letter from IDPH, Closure of nine waste sites, January 11, 1996.

2) Letter from DOE-CH, regarding the lowa State College Dump Site, April 20, 1999.

3) Letter from IDPH, Closure of the Former lowa State College Dump Site, September 17, 2001.

4) Letter from IDPH, Closure of the Fire Service Institute Training Area, February 26, 2002. 
APPENDIX D (EPA and DOE Correspondences)

1) DOE-AMSO memorandum approving Laboratory's EMS, June 29, 2009.

2) EPA letter (RCRA Inspection), April 27, 2006. 


\subsection{EXECUTIVE SUMMARY}

This report summarizes the environmental status of Ames Laboratory for calendar year 2010. It includes descriptions of the Laboratory site, its mission, the status of its compliance with applicable environmental regulations, its planning and activities to maintain compliance, and a comprehensive review of its environmental protection, surveillance and monitoring activities.

Ames Laboratory is located on the campus of lowa State University (ISU) and occupies 12 buildings owned by the Department of Energy (DOE). See the Laboratory's Web page for locations and Laboratory overview. The Laboratory also leases space in ISU owned buildings.

In 2010, the Laboratory accumulated and disposed of waste under U.S. Environmental Protection Agency (EPA) issued generator numbers. All waste is handled according to all applicable EPA, State, Local regulations and DOE Orders. In 2006 the Laboratory reduced its generator status from a Large Quantity Generator (LQG) to a Small Quantity Generator (SQG). EPA Region VII was notified of this change.

The Laboratory's RCRA hazardous waste management program was inspected by EPA Region VII in April 2006. There were no notices of violations. The inspector was impressed with the improvements of the Laboratory's waste management program over the past ten years.

The Laboratory was in compliance with all applicable federal, state, local and DOE regulations and orders in 2010.

There were no radiological air emissions or exposures to the general public due to Laboratory activities in 2010. See U.S. Department of Energy Air Emissions Annual Report in Appendix B.

As indicated in prior SERs, pollution awareness, waste minimization and recycling programs have been in practice since 1990, with improvements implemented most recently in 2010. Included in these efforts were battery and CRT recycling, miscellaneous electronic office equipment, waste white paper and green computer paper-recycling and corrugated cardboard recycling. Ames Laboratory also recycles/reuses salvageable metal, used oil, foamed polystyrene peanuts, batteries, fluorescent lamps and telephone books.

Ames Laboratory reported to DOE-Ames Site Office (AMSO), through the Laboratory's Performance Evaluation Measurement Plan, on its Affirmative Procurement Performance Measure. A performance level of "A-" was achieved in 2010 for Integrated Safety, Health and Environmental Protection.

As reported in Site Environmental Reports for prior years, the Laboratory's Environmental Management System (EMS) has been integrated into the Laboratory's Integrated Safety Management System since 2005. The integration of EMS into the way the Laboratory does business allows the Laboratory to systematically review, address and respond to the Laboratory's environmental impacts. The Laboratory's EMS was audited in April 2009 by DOE- CH. There were four "Sufficiently in 
Conformity" findings as a result of the audit. All four findings were tracked in the Laboratory's corrective action database for completion.

Beryllium was used routinely at Ames Laboratory in the 1940's and 1950's in processes developed for the production of highly pure uranium and thorium in support of the historic Manhattan Project. Laboratory metallurgists also worked on a process to produce pure beryllium metal from beryllium fluoride. In the early 1950's, beryllium oxide powder was used to produce shaped beryllium and crucibles. As a result of that work, beryllium contamination now exists in many interstitial spaces (e.g., utility chases) and ventilation systems in Wilhelm, Spedding and Metals Development buildings. Extensive characterization and remediation efforts have occurred in 2009 and 2010 in order to better understand the extent of the contamination. Analysis of extensive sampling data suggests that a fairly wide dispersion of beryllium occurred (most likely in the 1950's and 60's) in Wilhelm Hall and in certain areas of Spedding Hall and Metals Development. Area air-sampling results and work-area surface characterizations indicate the exposure potential to current workers, building visitors and the public remains extremely low. This information is now used to guide cleaning efforts and to provide worker protection during remodeling and maintenance activities. Results were shared with the DOE's Former Worker Program to support former worker medical testing and compensation programs. A complete discussion of the Laboratory's beryllium characterization and remediation efforts can be found at: http://www.ameslab.gov/operations/esha/beryllium-information. 


\section{Ames Laboratory Site Environmental Report Feedback Form}

This feedback form is provided to solicit public input on the development and improvement of future SER's. Public input is encouraged and appreciated. Remove and copy as needed. Attach additional pages as needed or send comments to kayser@ameslab.gov.

Return to: Ames Laboratory Environment, Safety, Health \& Assurance G40 TASF, lowa State University

Ames, IA 50011-3400

ATTN: Dan Kayser

1. What prompted your interest in environmental activities at Ames Laboratory?

2. In what ways can this report document and/or format be improved?

3. Do you have any questions on specific items or issues in this report?

4. Do you have any other comments? 


\subsection{INTRODUCTION}

\subsection{Site Description}

Ames Laboratory is a U.S. DOE facility located on the campus of lowa State University (ISU) at Ames, lowa. See the Laboratory's Web page for locations and Laboratory overview. Ames is a government-owned, contractor-operated (GOCO) facility. ISU is the Laboratory's contractor. The Technical and Administrative Services Facility (TASF) houses most of the Laboratory's management offices. The buildings owned by the Department of Energy (DOE) are listed below.

Building

Spedding Hall

Metals Development Building

Wilhelm Hall

TASF

Campus Warehouse Building

Mechanical Maintenance Building

Paint and Air Conditioning Shops

Construction Storage Shed

Storage Shed

Records Storage

Storage Shed 1

Storage Shed 2

Total DOE Owned

\section{Gross Square Feet}

107,630

69,663

56,541

46,991

16,506

8,540

4,954

4,398

2,100

1,679

1,461

1,702

\section{2,165}

In addition to the buildings owned by the DOE, Ames Laboratory leased a net total of 33,030 square feet of space from ISU in 2010.

The City of Ames, lowa surrounds the ISU main campus. In 2010 the population of Ames was approximately 56,814 , which includes the ISU student population of approximately 25,400 . Ames is located in Story County, which has a population of approximately 86,754 .

The climate is temperate continental, and is subject to wide temperature and precipitation ranges throughout the year. Mean monthly temperature varies from a low of minus 7.5 degrees Celsius $\left(18.5^{\circ} \mathrm{F}\right)$ in January to a high of 23.8 degrees Celsius $\left(74.8^{\circ} \mathrm{F}\right)$ in July. Average rainfall equivalent precipitation varies from 1.8 centimeters (0.7 inches) in January to 13.7 centimeters (5.4 inches) in June.

The region's topography is gently rolling with a slight overall negative gradient to the southeast. Under the shallow topsoil, the soils are glacial till with a depth of approximately 19.8 meters ( 65 feet). This material is underlain by predominantly limestone bedrock. In the central campus area, the depth to first groundwater is approximately 3.0 meters (10 feet). At the Applied Science Complex site depth to groundwater averages approximately 5.5 meters (18 feet). Surface run-off from both 
areas flows into Squaw Creek, a tributary of the South Skunk River. The streams have a combined average daily flow of approximately 644 million liters (170 million gallons).

\subsection{Organization and Administration}

Iowa State University operates Ames Laboratory for the United States government under Contract Number DE-AC02-07CH11358 with the U.S. DOE. The DOE Office of Science, through the Ames Site Office, administers the contract. In 2010, the Laboratory employed a total of 848 people. 466 full and part time employees and 382 associate (non-payroll) employees. See Organizational Chart, Figure 2.2-1.

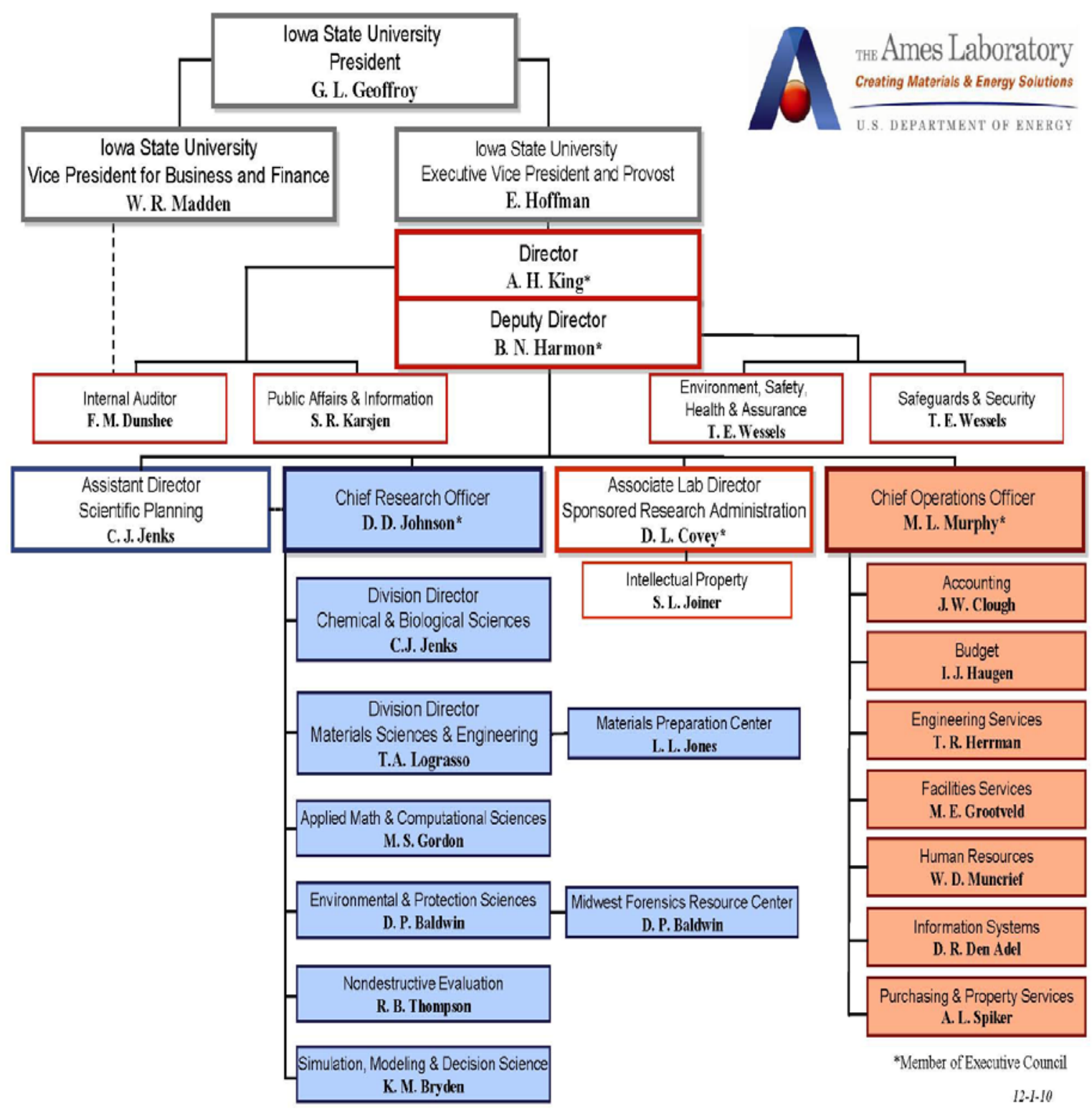

Figure 2.2-1 Organizational Chart 


\subsection{Mission}

The Laboratory's mission is to conduct fundamental research in the physical, chemical, materials, and mathematical sciences and physics, which underlie energy generating, conversion, transmission and storage technologies, environmental improvement, and other technical areas essential to national needs. These efforts will be maintained so as to contribute to the achievement of the Department of Energy's missions and goals; more specifically, to increase the general level of scientific knowledge and capability, to prepare engineering and physical sciences students for future scientific endeavors, and to initiate nascent technologies and practical applications arising from the Laboratory's scientific programs.

The Laboratory will approach all of its operations with the safety and health of all workers as a constant objective and with genuine concern for the environment. Ames Laboratory does not conduct classified research.

\subsection{Purpose of Site Environmental Report}

The primary purpose of this report is to summarize the performance of Ames Laboratory's environmental programs, present highlights of significant environmental activities, and confirm compliance with environmental regulations and requirements for calendar year 2010. This report is a working requirement of Department of Energy Manual 231.1-1A Chg. 1, Environment, Safety, and Health Reporting Manual". 


\subsection{COMPLIANCE SUMMARY}

\subsection{Calendar Year 2010 Compliance Status}

The Laboratory was in compliance with all applicable environmental regulations in 2010.

\subsection{Comprehensive Environmental Response, Compensation and Liability Act (CERCLA)}

There were no sites regulated under CERCLA.

Proper public comment periods have been observed for former site restoration activities (See section 5.7). The community advisory group (CAG), formed in May 1994, was and is the primary vehicle for public input to these activities. The CAG has been inactive over the past several years. The most recent interaction with CAG members includes a letter regarding the Energy Employees Occupational Illness Compensation Program Act (EEOICPA) and a letter regarding the Laboratory's support of the Special Exposure Cohort Petition for employees who worked at the Laboratory from 1942-1955.

EEOICPA's mission is to deliver benefits to eligible employees and former employees of the Department of Energy, its contractors and subcontractors or to certain survivors of such individuals, as provided in the EEOICP Act.

\subsection{Resource Conservation and Recovery Act (RCRA)}

Ames Laboratory is a government-owned, contractor-operated (GOCO) facility. All waste generated by Ames Laboratory under the contract with DOE is DOE waste. In 2010, DOE had one active RCRA site and two inactive sites. (See the summary table in section 3.17). Activities associated with the main campus EPA ID number were those of a small quantity generator (SQG). In calendar year 2010, $1099 \mathrm{~kg}$ of hazardous waste was properly disposed of through a contracted vendor. Figure 3.3-1 shows a reduction in RCRA hazardous waste over the past six years with a slight increase in 2010 due to a biorenewables research group moving to a new lowa State University building.

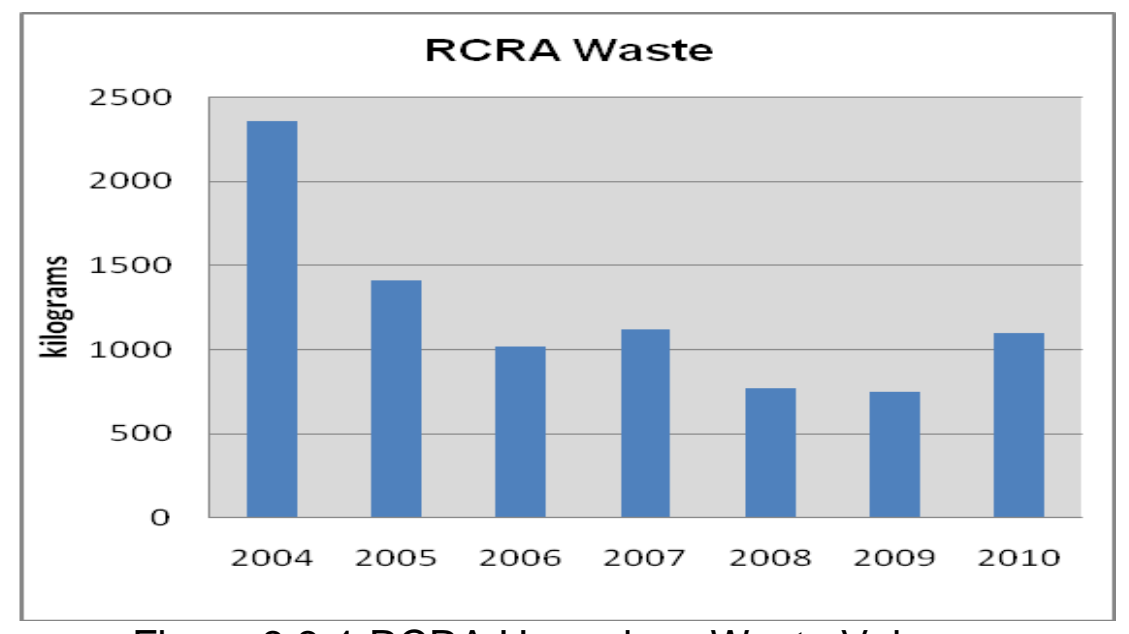

Figure 3.3-1 RCRA Hazardous Waste Volumes 
The former Waste Handling Facility (WHF) and the former Chemical Disposal Site (CDS) have been designated by EPA as "non-generator" sites.

The WHF was demolished in 2006 (See section 5.7.5). The CDS waste removal was completed in 1995 (See section 5.7.1 and correspondences in APPENDIX A).

The Laboratory's biennial report (aka: Hazardous Waste Report) is a report of RCRA waste removed from a facility that is required by the EPA every two years for large quantity generators (LQG). The report was completed and submitted, to the EPA, in January 2006 for the 2005 calendar year. The Laboratory is no longer required to submit this report as it is registered as a small quantity generator (SQG).

The Laboratory generates small amounts of low-level waste (LLW) from legacy contaminated buildings during renovation activities. Approximately 2-3 cubic meters of LLW are generated each year. The Laboratory has approximately 10-15 cubic meters in storage. LLW is typically shipped offsite for proper disposal every 3-4 years. A LLW shipment is tentatively scheduled for 2012 or 2013.

The Laboratory disposed of wastes at an out of state EPA permitted facility. There were two shipments of RCRA waste and no shipments of low-level radioactive waste in 2010. No mixed waste was generated or disposed of in 2010.

The Laboratory had no underground storage tanks (UST's) in 2010. The last UST (emergency generator diesel fuel) was removed in August 1995. It was replaced with an aboveground, double walled diesel tank with interstitial leak detection. There were no problems associated with the tank in 2010.

\subsection{Federal Facilities Compliance Act (FFCA)}

The FFCA is part of 42 USC 6901 and amends a part of RCRA. FFCA requires the preparation of site treatment plans for the handling of mixed wastes. EPA approved the Ames Laboratory Site Treatment Plan (STP) in January 1996.

Two waste streams were not included in the final STP because the Laboratory found process treatments that avoided creating mixed waste and, therefore, avoided the effort and expense of managing mixed wastes: 1) transuranic waste was managed according to applicable state and federal regulations as well as applicable DOE orders.

Transuranic solutions were neutralized and stabilized in the fall of 2000 . The stabilized material $\left(0.25 \mathrm{~m}^{3}\right)$ was sent to Hanford as LLW in $\left.2001 ; 2\right)$ contaminated lead was eliminated from the STP because in-process treatment prevents it from meeting the definition of mixed waste.

Any newly generated mixed waste will be handled and disposed of according to EPA, state, local and DOE orders. 
All research activities in 2010 were covered under the Laboratory's "site-wide" categorical exclusion for "Indoor Bench-Scale Research Projects and Conventional Laboratory Operations" which was submitted and approved by DOE-AMSO. This exclusion is valid through July 2011. Routine facility upgrades and renovations are covered under the Laboratory's "site-wide" categorical exclusion; "Renovations and maintenance activities for buildings, structures, infrastructures and equipment" which was also approved by DOE-AMSO and is valid until July 2011. These "site-wide" CXs eliminate unnecessary documentation but will still uphold the integrity of NEPA. Categorical exclusions are classes of actions that DOE (10 CFR 1021 Subpart D, App. B) has determined do not individually or cumulatively have a significant effect on the environment and do not require the preparation of either an environmental assessment or an environmental impact statement.

\subsection{Clean Air Act (CAA) and National Emissions Standards for Hazardous Air Pollutants (NESHAPS)}

U.S. EPA Region VII has delegated CAA authority to the State of lowa Department of Natural Resources (IDNR). The IDNR issued an official ruling for Ames Laboratory on July 18, 1994, stating that no permitting and no monitoring is required for the Laboratory's fume hoods.

The Laboratory maintains two construction air permits which were issued by the IDNR in December 1996. These are for the paint booth and sand blaster. The Laboratory also has nine exempt air emission sources. (See section 3.17 for a summary of permits).

The Laboratory was in compliance with all CAA requirements, including the NESHAP regulations for radionuclide emissions from DOE facilities. The Laboratory used small quantities of chemicals and radioactive materials for laboratory bench-top research and development activities in 2010. The Laboratory did not have any air emissions in 2010 that could have exposed the public to radioactivity (See correspondences in APPENDIX B).

\subsection{Clean Water Act (CWA)}

Ames Laboratory does not have any point sources of effluents requiring National Pollutant Discharge Elimination System (NPDES) permits. The Laboratory discharges all liquid wastes to the ISU sanitary sewer system, which discharges into the City of Ames sanitary sewer system. The City of Ames has an NPDES permit. The City of Ames has an agreement for wastewater pre-treatment with ISU, which includes Ames Laboratory's wastewater. Both the City of Ames and ISU sampled the university's wastewater effluent using EPA protocols and methods in 2010 as part of this agreement. Since existing DOE buildings are on land leased from ISU, the ISU stormwater permit (MS4s) covers Ames Laboratory activities. The Laboratory discharged approximately 5,446,030 gallons of wastewater to ISU's sanitary sewer system in 2010. This was 2.8 percent of the total discharged from ISU's campus buildings. The university discharged 191,807,744 gallons of wastewater to the City of Ames sewer system. 
Under 40 CFR Part 112 the Laboratory is required to have a Spill Prevention, Control and Countermeasure (SPCC) Plan as the Laboratory meets the 1,320 gallon storage capacity threshold for oil storage. The Laboratory's Plan is part of lowa State University's overall Plan.

\subsection{Safe Drinking Water Act (SDWA)}

Drinking water for the Laboratory is supplied by the City of Ames public water system through the university's water mains. The Ames public water system is tested by the city to verify SDWA standards are being met. The Laboratory used 5,446,030 gallons of potable water in 2010 , approximately 2.0 percent of the $288,096,503$ gallons used by the university.

Ames Laboratory drinking fountains are sampled by Ames Laboratory Facility Services. Fountains were sampled for lead in 2008. Historical data shows no evidence of lead in drinking water. Drinking water will be sampled every three years. Results are summarized in Table 3.8-1.

Table 3.8-1

Drinking Fountain Analysis

\begin{tabular}{|c|c|c|c|c|c|c|}
\hline $\begin{array}{l}\text { Building } \\
\text { Location }\end{array}$ & $\begin{array}{c}2000 \text { Lead } \\
(\mathrm{mg} / \mathrm{l})\end{array}$ & $\begin{array}{c}2001 \text { Lead } \\
\text { (mg/L) }\end{array}$ & $\begin{array}{c}2002 \\
\text { (mg/L) }\end{array}$ & $\begin{array}{c}2003 \\
(\mathrm{mg} / \mathrm{L})\end{array}$ & $\begin{array}{c}2005 \\
\text { (mg/L) }\end{array}$ & $\begin{array}{c}2008 \\
(\mathrm{mg} / \mathrm{L})\end{array}$ \\
\hline $\begin{array}{l}\text { Spedding Hall, } \\
1^{\text {st }} \text { floor west } \\
\text { hallway }\end{array}$ & $<0.002$ & & & & & \\
\hline $\begin{array}{l}\text { Spedding Hall, } \\
\text { ground floor east } \\
\text { hallway }\end{array}$ & & $<0.002$ & $<0.005$ & $<0.005$ & $<0.005$ & \\
\hline $\begin{array}{l}\text { Spedding Hall, } \\
\text { ground floor west } \\
\text { hallway }\end{array}$ & & & & & & $<0.001$ \\
\hline $\begin{array}{l}\text { Wilhelm Hall, } 3^{\text {rd }} \\
\text { floor east hallway }\end{array}$ & $<0.002$ & $<0.002$ & $<0.005$ & $<0.005$ & $<0.005$ & $<0.001$ \\
\hline $\begin{array}{l}\text { Metals } \\
\text { Development, } \\
\text { room } 158\end{array}$ & $<0.004$ & $<0.002$ & $<0.005$ & $<0.005$ & $<0.005$ & $<0.001$ \\
\hline
\end{tabular}

* The regulatory limit for lead is $0.015 \mathrm{mg} / \mathrm{l}$.

3.9 Superfund Amendments and Reauthorization Act (SARA) Title III and lowa Administrative Code (IAC), Rule 567, Chapter 131, Spill Response

The Laboratory was required to report sulfuric acid from lead acid batteries, as volumes exceeded the 500 pound threshold reporting limit, under the Emergency Planning \& Community Right to Know Act (EPCRA) Section 312. Sulfuric acid from fork trucks and banks of batteries (UPSs) are not exempt and therefore must be counted. Laboratory research chemicals are exempt from sections 302-303, 311-312 and 313. The Laboratory did not store any research related chemicals in excess or near EPCRA threshold limits in 2010. The Laboratory does maintain memorandums of 
understanding (MOU) with the lowa State University Department of Pubic Safety and the City of Ames Fire Department for emergency and hazardous material situations. Copies of MOU's are located in the "Ames Laboratory Emergency Plan". The Laboratory was not required to report under EPCRA Section 304 as there were no reportable releases in 2010.

Spills to the environment are reported to the lowa Department of Natural Resources (IDNR) in accordance with the IAC, Rule 567, Chapter 131. Spills are cleaned up in accordance with the IAC, Rule 567, Chapter 133. There is no minimum reportable quantity under Chapter 131. There were no reportable spills or releases in 2010. Reportable spills, releases and occurrences are entered in DOE's Occurrence Reporting and Processing System (ORPS) as prescribed in DOE Manual 231.1-2. The Laboratory also reports any "reportable" spills/releases to DOE-AMSO.

Table 3.9-1

Status of EPCRA Reporting

\begin{tabular}{|l|l|c|}
\hline \multicolumn{1}{|c|}{ EPCRA Section } & Description of Reporting & \multicolumn{1}{c|}{ Status } \\
\hline EPCRA Sec. 302-303 & Planning Notification & Not Required \\
\hline EPCRA Sec. 304 & EHS Release Notification & Not Required \\
\hline EPCRA Sec. 311-312 & MSDS/Chemical Inventory & $\begin{array}{c}\text { Required for Sulfuric Acid in } \\
\text { batteries/ Voluntarily } \\
\text { Reporting for research } \\
\text { chemicals }\end{array}$ \\
\hline EPCRA Sec. 313 & TRI Reporting & Not Required \\
\hline
\end{tabular}

\subsection{Toxic Substances Control Act (TSCA)}

No asbestos containing materials (ACM) were disposed of in 2010 as renovation activities during the year generated only minimum quantities which were disposed in 2011. Ames Laboratory ACM was disposed of in the Ames-Story Environmental Landfill. The landfill is permitted to accept ACM under IDNR issued permit number 85SDP-13-91P. The Laboratory complies with the State of Iowa Solid Waste Disposal Rule \#102.14 and 40 CFR 61, Subpart M (asbestos NESHAP) when disposing of ACM. Figure 3.10-1 shows ACM volumes over the past seven years. ACM volumes are determined by the level of renovation activities (i.e. floor tile, fume hoods, and pipe insulation). 


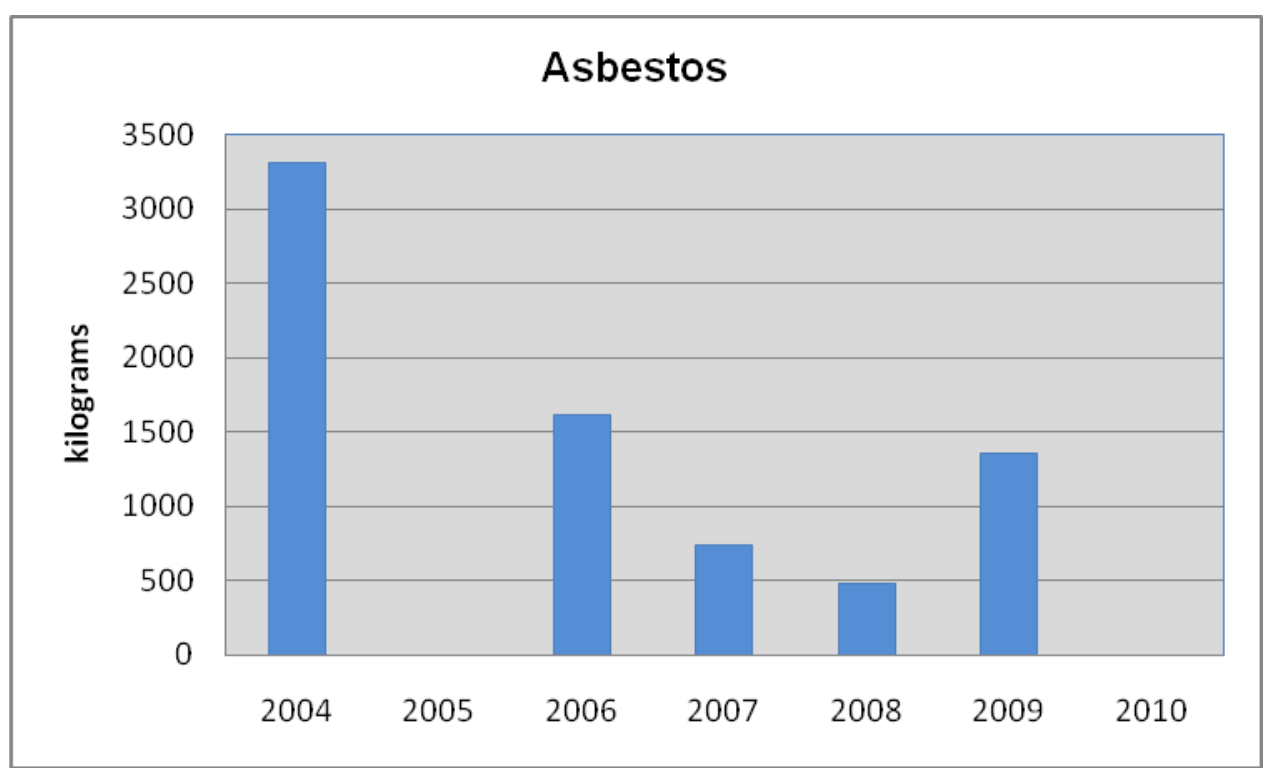

Figure 3.10-1 Asbestos Volumes

Approximately $175 \mathrm{~kg}$ of PCB ballasts were properly disposed in 2010 through the Laboratory's hazardous waste vendor. Figure 3.10-2 shows PCB volumes over the past seven years.

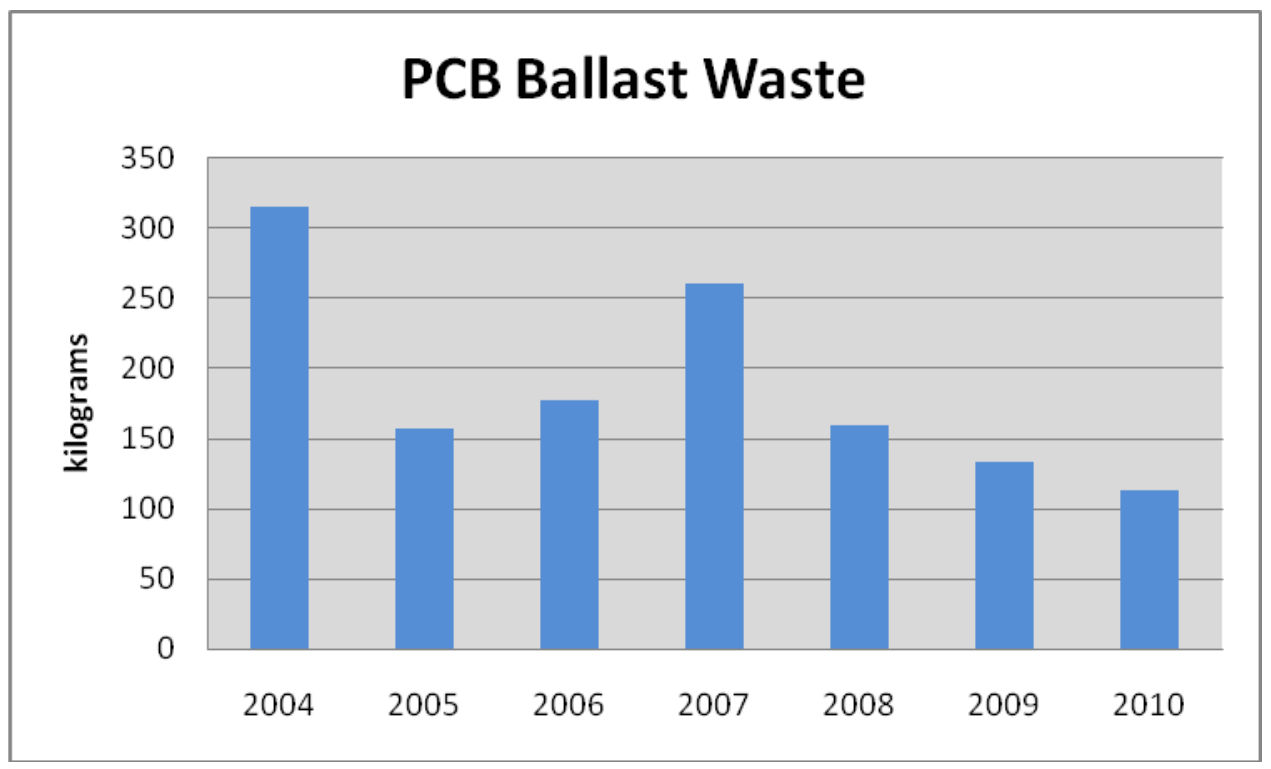

Figure 3.10-2 PCB Volumes 


\subsection{Federal Insecticide, Fungicide, and Rodenticide Act (FIFRA)}

Ames Laboratory does not purchase or use pesticides regulated by FIFRA. Pesticide spraying is done in portions of buildings by a licensed applicator using approved chemicals.

\subsection{Endangered Species Act (ESA)}

No endangered species have been identified on or near Ames Laboratory facilities or Laboratory controlled areas.

\subsection{National Historic Preservation Act (NHPA)}

The State Historic Preservation Officer (SHPO) was contacted in 1997. As a result of this meeting the SHPO stated that there are no historic districts on the ISU Campus or in the City of Ames. As of September 16, 1997, there are nine structures on ISU's campus that are on the state historic register. None of these buildings are associated with Ames Laboratory activities.

DOE-owned buildings at the Ames Laboratory are on land leased to DOE by lowa State University. A detailed building survey (Historical \& Architectural Survey \& Evaluation) was conducted in June 2009 as required by the National Historic Preservation Act Section 110. The building survey was conducted by a contracted architectural historian. The Historical \& Architectural Survey \& Evaluation report indicates that three Ames Laboratory buildings could be nominated to the National Historic Registry. DOE, in consultation with the SHPO, will determine eligibility for listing on the National Register for Historical Places. At this time the DOE is not pursuing nomination of these three buildings (Spedding Hall, Wilhelm Hall and Metals Development). However, any adverse impact to an eligible building would be mitigated in consultation with the SHPO.

The Ames Laboratory procedure for identifying hazards prior to disposition of excess materials requires that excess items be evaluated for historical significance.

\subsection{Migratory Bird Treaty Act}

There are over 200 bird species that may migrate through Ames, IA. However, there are no activities at the Ames Laboratory that affect migratory birds.

\subsection{Executive Order 11988, "Floodplain Management"}

All Laboratory facilities are well outside the 100-year flood line as mapped by the U.S. Geological Survey (USGS) and the lowa Geological Survey Bureau (GSB). The Lab is in full compliance with 10 CFR 1022. 


\subsection{Executive Order 11990, "Protection of Wetlands"}

No wetlands are affected by Ames Laboratory activities. The Lab is in full compliance with 10 CFR 1022.

\subsection{Summary of Permits}

In 2010, Ames Laboratory had two air emission source construction permits, it had no environmental discharge, operational, storage, treatment or disposal permits for gaseous, liquid or solid effluents. DOE held three waste generator identification numbers for Ames Laboratory in 2010, although two of the sites were inactive. In 2006 the Laboratory switched from a Large Quantity Generator (LQG) RCRA status to a Small Quantity Generator (SQG) status.

Table 3.17-1

\section{DOE RCRA Generator Identification Numbers}

\begin{tabular}{|l|c|l|c|}
\hline RCRA Generator ID \# & Type & \multicolumn{1}{|c|}{ Ames Laboratory FacilitylArea } & Expiration \\
\hline IA6890008950 & SQG & Ames Lab \#3-DOE (main campus) & None \\
\hline${ }^{*}$ IAD984617605 & CESQG & Ames Lab \#1-DOE (Waste Handling Facility) & None \\
\hline${ }^{*}$ IA0000365973 & SQG & Ames Lab \#2-DOE/ISU (chemical disposal site) & None \\
\hline
\end{tabular}

* Both sites have been designated by the EPA as "non-generators". 
Table 3.17-2

\section{Ames Laboratory Air Emission Sources}

\begin{tabular}{|l|c|l|l|}
\hline \multicolumn{1}{|c|}{ Description } & Permit Number & Location & Regulatory Citation \\
\hline $\begin{array}{l}\text { Paint Spray Booth - } \\
\text { Construction Permit }\end{array}$ & $96-A-1282$ & Paint Booth & $\begin{array}{l}567 \text { IAC 22.3 and } \\
\text { IAC 23.4(13) }\end{array}$ \\
\hline $\begin{array}{l}\text { Sand Blaster - Construction } \\
\text { Permit }\end{array}$ & $96-A-1283$ & $\begin{array}{l}\text { Mechanical Maintenance } \\
\text { Building }\end{array}$ & $\begin{array}{l}567 \text { IAC 22.3 and } \\
\text { IAC 23.4(6) }\end{array}$ \\
\hline Graphite Lathe - Exempt & NA & Metals Development Building & 567 IAC 22.1(2)u \\
\hline $\begin{array}{l}\text { Graphics Spray Booth - } \\
\text { Exempt }\end{array}$ & NA & TASF - 132 & 567 IAC 22.1(2)o \\
\hline $\begin{array}{l}\text { Dust Collector - Exempt } \\
\text { Compactor - Small Unit } \\
\text { Exemption }\end{array}$ & NA & Wood Shops & 567 IAC 22.1(2)u \\
\hline $\begin{array}{l}\text { Engineering Services Shop } \\
\text { Exhaust - Exempt }\end{array}$ & NA & $\begin{array}{l}\text { Mechanical Maintenance } \\
\text { Building - RWA } \\
-160\end{array}$ & 567 IAC 22.1(2)w(I) \\
\hline $\begin{array}{l}\text { Engineering Services Shop } \\
\text { Welders - Exempt }\end{array}$ & NA & $\begin{array}{l}\text { Metals Development Building } \\
-160\end{array}$ & 567 IAC 22.1(2)p \\
\hline Diesel Generators - Exempt & NA & Wilhelm Hall & 567 IAC 22.2(2)r \\
\hline $\begin{array}{l}\text { Canopy Hood in Paint Shop - } \\
\text { Small Unit Exemption }\end{array}$ & NA & Paint Shop & 567 IAC 22.1(2)w(1) \\
\hline $\begin{array}{l}\text { Laboratory Fume Hoods - } \\
\text { Exempt }\end{array}$ & NA & SPH, HWH, MD & 567 IAC 22.1(2)s \\
\hline
\end{tabular}




\subsection{ENVIRONMENTAL PROGRAM}

\subsection{Environmental Management System}

The Laboratory's Environmental Management System (EMS) is incorporated into the Laboratory's Integrated Management System (ISMS).

\subsubsection{EMS Effectiveness}

The Laboratory's EMS has been effective according to the EMS Self-Assessment performed on December 14, 2010. Due to basic research at the Laboratory environmental aspects do not drastically change. However, with the integration into the Laboratory's Integrated Management System (ISMS) there are systems in place to adequately detect new environmental aspects and impacts. The Laboratory has an Environmental Management System Steering Committee that consists of researchers, safety personnel, facilities personnel, transportation and procurement personnel. This group is tasked with recommending energy savings goals and the prevention of pollution for the Laboratory. These recommendations are tracked in the Laboratory's database (Ames Laboratory Corrective Action Tracking System - ALCATS). Energy usage was determined to be the significant aspect (largest impact on the environment) for the Laboratory. The Laboratory has taken measures (i.e. facility upgrades, education, reduced lighting strategies) and continues to look at other areas of energy conservation. The group has also been instrumental in developing new training aids to promote and maintain the Laboratory's EMS.

The Laboratory achieved its CY2010 EMS goals. The Laboratory reduced its white paper usage by $10 \%$ and reduced fume hood discrepancies by $20 \%$. The Laboratory also started collecting corrugated cardboard to be recycled. The Laboratory's monthly publication of the Insider is now paperless. It has become a web based "publication".

The Laboratory's EMS was audited by DOE-CH (April 2009) as required by DOE Order 450.1A. Four "Sufficiently in Conformity" findings were made. All four findings were corrected and the Laboratory's EMS was considered fully implemented according to DOE Order 450.1A with concurrence with DOE-AMSO on June 29, 2009 (see attached correspondence in Appendix D).

\subsection{Pollution Awareness, Waste Minimization and Recycling Programs}

As indicated in prior SERs, pollution awareness, waste minimization and recycling programs have been in practice since 1990, with improvements implemented most recently in 2010. The plan conforms to Executive Order 13423 and Executive Order 13514. Elements of the plan include:

$>$ A statement of management support and commitment.

$>$ A waste minimization policy for the Laboratory.

$>$ Goals.

$>$ Waste minimization and recycling activities.

$>$ Employee awareness. 
The Laboratory was engaged in waste minimization activities in 2010. These activities helped reduce the quantities of non-hazardous and hazardous wastes generated by the Laboratory. Examples include:

$>$ Steel recycling.

$>$ White paper and computer paper are recycled.

$>$ Styrofoam peanut recycling.

$>$ Chemical surplus redistribution.

$>$ Telephone book recycling.

$>$ Fluorescent bulb recycling.

$>$ CRT recycling.

$>$ Battery recycling.

$>$ Corrugated Cardboard

All other non-hazardous waste generated by the Laboratory was collected and transported to the City of Ames' Resource Recovery Plant for processing. Combustible waste is used as fuel in the city's electrical utility power plant. Scrap metal from uncontrolled areas is sent offsite for recycling.

Waste generation, recycling and environmentally preferred purchasing data are entered every fiscal year into DOE's pollution prevention web based database. Data reports can be accessed on DOE's Office of Health, Safety and Security Pollution Prevention website.

Ames Laboratory's Facilities Services is capable of recovering R-12 refrigerants, except from vehicles, and R-22 refrigerants for recycling or disposal. Recovery equipment is registered with EPA Region VII under Number 608. Freon is recycled through the Laboratory's waste disposal vendor.

The Laboratory's Executable Plan outlines the Laboratory's commitment to meeting Executive Order 13423 \& 13154 sustainability goals.

\subsection{Performance Measures}

For calendar year 2010, Ames Laboratory reported to DOE-AMSO through the Laboratory's Performance Evaluation and Measurement Plan on its affirmative procurement performance within a measure entitled, "Provide Efficient and Effective Waste Management, Minimization and Pollution Prevention". The Laboratory strives to purchase EPA-designated items to the maximum extent practicable, and has achieved adequate performance. 


\subsection{ENVIRONMENTAL RADIOLOGICAL PROGRAM}

\subsection{DOE Order 5400.5, "Radiation Protection of the Public and the Environment"}

Ames Laboratory has prepared guidance documents, which are based on the environmental radiation release criteria specified in DOE Order 5400.5. There were no detectable or reportable radiological releases to the environment in 2010 (See U.S. Department of Energy Air Emissions Annual Report, Calendar Year 2010 in Appendix B).

\subsection{DOE Order 435.1, "Radioactive Waste Management"}

The majority of the Laboratory's radioactive waste is generated through renovation activities that occur in DOE buildings. These buildings were contaminated by past activities. All waste generated is low-level waste. The Laboratory has written procedures to manage these radioactive materials.

\subsection{Property Release}

In accordance with the Secretary of Energy's memorandum dated January 1, 2001, which suspended the unrestricted release for recycling of metal from radiological areas, as defined by 10 CFR 835.2 and the Secretary's memorandum on January 19, 2001, Managing the Release of Surplus and Scrap Materials, the Laboratory will utilize this guidance to determine the proper disposition of radiologically contaminated property.

\subsection{Radiation Emissions and Doses}

There were no point source releases from the Ames Laboratory complex in 2010. Diffuse source emissions were limited to low-level waste activities and renovation activities. Emissions from these activities were minimized or eliminated by engineering devices/structures, when necessary (e.g. containment cells with HEPA filtration).

Using the guidance in 40 CFR 61.94, the annual radionuclide NESHAPS report was prepared. According to the guidance, and based on the isotope inventory in curies per year used at the Laboratory, air emissions were not required to be monitored. IDNR and IDPH do not require permits or monitoring for laboratory fume hoods under Chapter 20 IAC 567 22.1(2) (1). However, Appendix D to 40 CFR Part 61 does provide a method for estimating the radionuclide emissions for a year, for reporting purposes, based on the amount of radionuclides in curies used at a facility. The required parameters were used to calculate potential dose equivalent to the public due to estimated radionuclide emissions from the Laboratory (See correspondences in APPENDIX B).

\subsection{Unplanned Releases}

There were no planned, unplanned or accidental radiological releases from Ames Laboratory in 2010. 


\subsection{Environmental Monitoring}

Ames Laboratory performed no sampling of storm or sanitary sewer water in 2010 . The City of Ames samples twice each year and ISU (permittee) samples quarterly. The Chemical Disposal Site (CDS) ground water was not sampled in 2010. The last four wells at the CDS were plugged in March and April of 2009. Section 7.0 discusses groundwater and Table 5.7-1 contains groundwater data from 2002-2007.

\subsection{Areas of Concern}

Ames Laboratory, DOE, and ISU have addressed all known contaminated sites in or near the City of Ames. There are no known areas of concern. The City of Ames has plans to develop a dog park at the location of the old sewage treatment plant site. This plan raised some concerns from a member of the community as this site was once contaminated with thorium. The site was released for unrestricted use in 1995 by state regulators. Documentation pertaining to the clean-up and release of the site was provided to the concerned individual. There were no more concerns.

\subsubsection{Chemical Disposal Site (CDS)}

The Chemical Disposal Site (CDS) was located north of Ontario Street on Scholl Road, east of lowa State University's Applied Sciences Complex in Ames, lowa. A chain-link fence surrounds the approximately 80,000 square feet site. The site and the surrounding area are owned by ISU.

The site was used by Ames Laboratory for the disposal of radioactive materials and hazardous chemicals from 1957 to 1966 . Nine unlined pits, used to bury radiological and chemical waste contained in steel pails, drums, and plywood boxes, were located at the southeast corner of the CDS's fenced area.

DOE remediated the CDS in 1994, and ISU completed characterization in 1998. Based on the characterization report, the lowa Department of Public Health released the CDS for unrestricted future use in October 1998 (See Appendix A, Letter to lowa State University from IDPH, October15, 1998).

In April, 1999, the license agreement between the Department of Energy and lowa State University was allowed to expire. ISU accepted responsibility for closure of the well and restoration activities associated with the well closure.

In June 1999, lowa State University received a U.S. Department of Energy Notice of Financial Assistance Award for the Ames Laboratory Chemical Disposal Site: Ground Water Monitoring Project. Groundwater Sampling was scheduled to be performed on an annual basis until 2002. ISU continued to perform additional sampling at the CDS through 2007.

Data (six years) from Table 5.7-1 indicates there is no threat to Squaw Creek or the public water supply. ISU discontinued sampling and will properly abandon the remaining wells (See correspondences in APPENDIX A). The last four monitoring wells were plugged in March and April of 2009. 
Table 5.7-1

\section{CDS Groundwater Analysis}

Gross Alpha

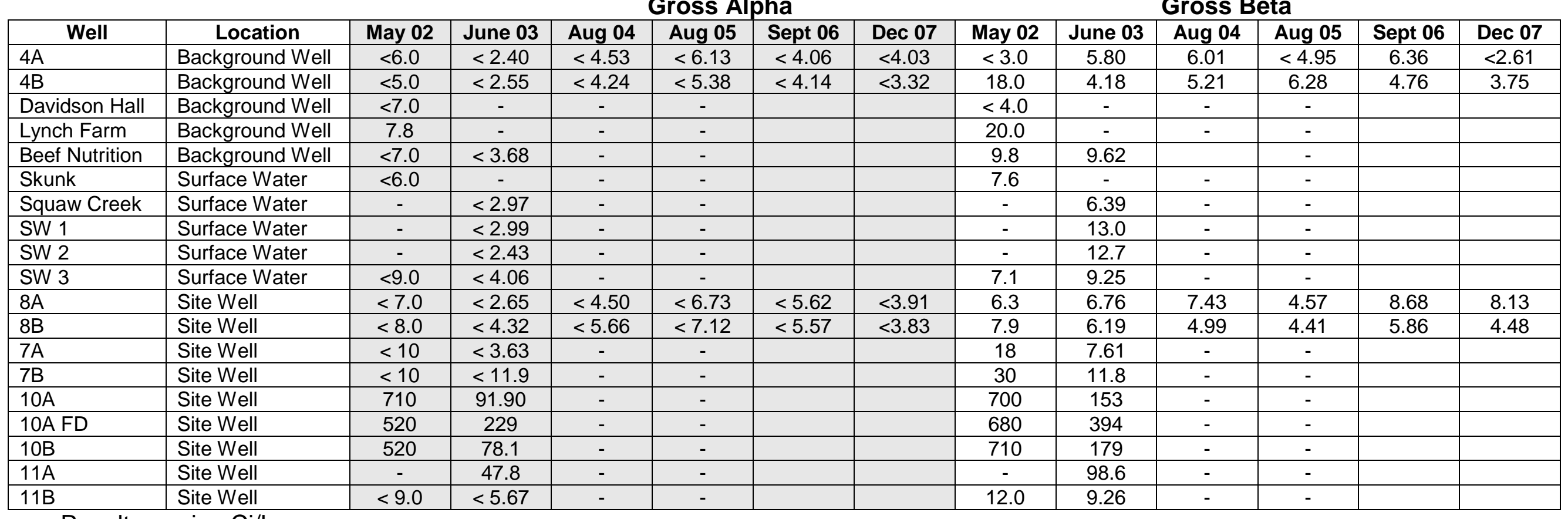

Results are in $\mathrm{pCi} / \mathrm{L}$. 


\subsubsection{Inactive Waste Sites (IWS)}

The regulators have released a total of 12 IWS's (See Correspondence in Appendix C). The status of the sites released follows.

\section{Site}

Old Sewage Plant

Grand Avenue Underpass

Ames Municipal Cemetery

Applied Sciences Complex

Block House

Little Ankeny Debris

Annex I

Annex II

Ames Municipal Airport

Chemical Disposal Site

Former lowa State College Dump Site

Fire Service Institute Training Area

\section{Release Status}

Unrestricted use

Unrestricted use

Unrestricted use

Unrestricted use

Unrestricted use

Unrestricted use

Approved for current use

Approved for current use

Approved for current use

Unrestricted use

Unrestricted use

Unrestricted use
Date Released

1995

1996

1996

1996

1996

1996

1996

1996

1996

1998

2001

2002

Additional information regarding these sites can be found in previous Site Environmental Reports or by contacting Ames Laboratory Public Affairs at 515-294-5643. 


\subsection{ENVIRONMENTAL NON-RADIOLOGICAL PROGRAM}

\subsection{Emissions Monitoring}

The Laboratory has two air permits that require mass balance monitoring. An annual log is required for each air permit. The log is monitored and reviewed to verify the Laboratory is not exceeding its permitted limits.

The Laboratory does not perform any other non-radiological monitoring (i.e. air, water or soil sampling). 


\subsection{GROUNDWATER MONITORING AND PROTECTION}

There are no current Ames Laboratory activities that pose a hazard to groundwater or surface water. The Laboratory has no underground storage tanks. Three DOE owned monitoring wells were abandoned June 2005. Currently there is no monitoring of the groundwater and lowa State University is not required to monitor groundwater on the main campus.

The CDS was monitored from $2002-2007$ as prescribed by the IDNR and IDPH (See data table 5-7.1). The wells were abandoned according to IDNR requirements by ISU in 2009 (See Correspondence in Appendix A). 


\subsection{QUALITY ASSURANCE PROGRAMS}

Radioactive sources and solutions that are used for calibration of radiation-detection instrumentation are obtained with quantitative calibration directly traceable to the National Institute of Standards and Technology. Ames Laboratory's quality assurance effort relied on established U.S. EPA, IDNR, IDPH, and DOE regulations, standards and methods. This applies to both radioactive and non-radioactive environmental sampling and analyses.

Ames Laboratory's air quality assurance procedure consists of maintaining an exhaust hood inventory, maintaining a radiological material balance, tracking chemicals, and waste collection and management. These measures determine if the Laboratory has a source in need of monitoring or permitting, in accordance with IDNR guidance. The Laboratory uses EPA's COMPLY modeling program, when necessary, to produce the annual NESHAP report (See Appendix B).

In 2010, the Laboratory continued to apply its Readiness Review (RR) Procedure to new or significantly modified research activities for risk identification, categorization, and ES\&H review of activities. Another purpose of the RR is to prevent and/or control releases of hazardous materials to the environment. It was developed to ensure that an appropriate level of rigor, commensurate to the risk associated with an activity's hazards, is applied to the activity's ES\&H review. Thirty-seven readiness reviews were approved in 2010. Approved activities are reviewed every five years.

Line management directs Laboratory Group/Section leaders to be responsible for assuring that measuring and test equipment is of proper type, accuracy, and tolerance to accomplish the specified requirements. 


\subsection{REFERENCES}

1. Ames City Manager's Office, demographic information.

2. Ames Laboratory Site Environmental Reports.

3. City of Ames and ISU Pretreatment Agreements \#3593-3 and \#4093-3.

4. DOE Manual 231.1-1A Chg 1, "Environment, Safety and Health Reporting Manual."

5. DOE Order 5400.5, "Radiation Protection of the Public and the Environment."

6. DOE Manual 470.4-6, "Nuclear Materials Control and Accountability."

7. Executive Order 13423, "Strengthening Federal Environmental, Energy, and Transportation Management". This replaced EO 13101.

8. Characterization Report for the Ames Laboratory Chemical Disposal Site, lowa Sate University, September 1998.

9. IATA Dangerous Goods Regulations

10. Iowa Administration Code, Rule 567, Chapters 20-24 and 28, "Air Quality."

11. Iowa Administration Code, Rule 567, Chapter 60, "Wastewater Treatment and Disposal: Definitions, Rules of Practice."

12. Iowa Administration Code, Rule 567, Chapter 61, "Water Quality Standards."

13. Iowa Administration Code, Rule 567, Chapter 100, 101, 109, 118, 119, "Solid Waste Management and Disposal."

14. Iowa Administration Code, Rule 567, Chapter 131, "Notification of Hazardous Conditions."

15. Iowa Administration Code, Rule 567, Chapter 133, "Determining Cleanup Actions and Responsible Parties."

16. Iowa Administration Code, Rule 567, Chapter 140 and 141, "Hazardous Waste."

17. 10 CFR Part 1021, "National Environmental Policy Act Implementation Procedures."

18. 10 CFR Part 835, "Occupational Radiation Protection."

19. 29 CFR Part 1910.120, "Hazardous Waste Operations and Emergency Response."

20. 40 CFR Part 63, "National Emission Standards for Hazardous Air Pollutants for Source Categories." 
21. 40 CFR Part 82, "Protection of Stratospheric Ozone."

22. 40 CFR Part 112, "Oil Prevention; Spill Prevention, Controls and Countermeasures."

23. 40 CFR Part 131, "Water Quality Standards."

24. 40 CFR Part 141, "National Primary Drinking Water Regulations."

25. 40 CFR Parts 260-264 (subpart S), 265 and 268, "Hazardous Waste Implementing Rules."

26. 40 CFR Part 279, "Standards for the Management of Used Oil."

27. 40 CFR Part 300, "National Oil and Hazardous Substances Pollution Contingency Plan."

28. 40 CFR Part 302, "Designation, Reportable Quantities and Notification."

29. 40 CFR Part 355, "Emergency Planning and Notification."

30. 40 CFR Part 761, "Polychlorinated Biphenyls (PCBs) Manufacturing, Processing Distribution in Commerce, and Use Prohibitions."

31. Consent Agreement and Consent Order, executed February $27^{\text {th }}, 1996$. 


\subsection{LIST OF ACRONYMS}

ASC: Applied Sciences Complex of lowa State University.

ALCATS: Ames Laboratory Corrective Action Tracking System.

AMSO: Ames Site Office

Bq: Becquerel, one disintegration per second.

CAA: Clean Air Act and Amendments.

CAG: Community Advisory Group for Ames Laboratory environmental activities.

CDS: Chemical Disposal Site

CERCLA: Comprehensive Environmental Response, Compensation and Liability Act.

CESQG: conditionally exempt small quantity generator.

CFR: Code of Federal Regulations.

CG: concentration guide, DOE derived.

CH: Chicago Operations Office of the U.S. Department of Energy.

Ci: Curie, 3.7E10 disintegration's per second.

CWA: Clean Water Act.

CX: categorical exclusion, a class of activities determined to have no environmental impact.

DOE: U.S. Department of Energy.

EA: environmental assessment.

EIS: environmental impact statement.

EMR: environmental management review.

EMS: environmental management system.

EPA: U.S. Environmental Protection Agency.

EPCRA: Emergency Planning and Community Right to Know Act.

ESA: Endangered Species Act. 
ESH\&A: Environment, Safety, Health and Assurance office of Ames Laboratory.

FFCA: Federal Facilities Compliance Act.

FIFRA: Federal Insecticide, Fungicide and Rodenticide Act.

FS: feasibility study.

FSP: field sampling plan.

GOCO: a government owned, contractor operated facility.

HEPA: high efficiency particulate air, a filter element or filtration system.

HQ: Headquarters of U.S. Department of Energy.

IAC: Iowa Administration Code.

IDNR: Iowa Department of Natural Resources.

IDPH: lowa Department of Public Health.

ISMS: Integrated Safety Management System.

ISU: Iowa State University.

IWS: inactive waste site.

LDR: land disposal restriction.

LQG: large quantity generator.

MCL: maximum contaminant level.

mg/L: milligrams per liter; equivalent to ppm.

mrem: millirem.

MS4s: Municipal Separate Storm Sewer Systems

mSv: millisievert, $10^{-3}$ Sieverts.

NEPA: National Environmental Policy Act.

NESHAP: National Emission Standards for Hazardous Air Pollutants.

NHPA: National Historic Preservation Act. 
NOV: notice of violation.

NPDES: National Pollutant Discharge Elimination System.

NRC: Nuclear Regulatory Commission.

ODS: ozone depleting substance.

PCB: polychlorinated biphenyls.

pCi: picocurie, $10^{-12}$ Curies.

PIDS: performance indicator database system.

QA: quality assurance.

QAP: Quality Assessment Program, DOE.

RCRA: Resource Conservation Recovery Act.

Rem: Roentgen equivalent man, radiation dose.

RESRAD: residual radiation model for sites.

RI: remedial investigation.

RPP: Radiological Protection Plan, for Ames Laboratory.

SARA: Superfund Amendments and Reauthorization Act.

SDWA: Safe Drinking Water Act.

SER: Site Environmental Report.

TASF: Technical and Administrative Support Facility, the Ames Laboratory office building.

TCLP: Toxicity Characteristic Leaching Procedure

TPQ: threshold-planning quantity.

TRU: transuranic waste.

TSCA: Toxic Substances Control Act.

WAS: work authorization system of Ames Laboratory. 


\subsection{REPORT DISTRIBUTION}

\section{Organization}

Ms. Cynthia Baebler, Manager

Ames Site Office 9800 South Cass Avenue

Argonne, IL 60439

Cynthia.baebler@ch.doe.gov

Mr. Justin Zamirowski, P.E., Assistant Manager

Office of Safety, Technical, and Infrastructure Services

DOE Chicago Office, Bldg 201

9800 South Cass Avenue

Argonne, IL 60439

Justin.Zamirowski@ch.doe.gov

Mr. Alan Handwerker, Chief Counsel

Office of Chief Counsel

DOE Chicago Office

9800 South Cass Avenue

Argonne, IL 60439

Alan.handwerker@ch.doe.gov

Mr. Glenn Podonsky, Chief, Health, Safety and Security Officer

Office of Health, Safety and Security,HS-1/Germantown Building

1000 Independence Ave., S.W.

Washington, DC 20585-1290

Glenn.podonsky@hq.doe.gov

Mr. Andrew Lawrence, Director, Office of Nuclear Safety and Environment Office of Nuclear Safety, Quality Assurance and Environment,HS-20/ FORS 1000 Independence, SW

Washington, DC 20585

Andrew.lawrence@eh.doe.gov

William Roege, Director, Office of Corporate Safety Analysis

Office of Corporate Safety Analysis,HS-30/Germantown Building

1000 Independence Ave., S.W.

Washington, DC 20585-1290

William.roege@hq.doe.gov

William Eckroade, Deputy, Chief for Operations

Office of the Chief Health, Safety and Security Officer 1/FORS Building 1000 Independence Ave., S.W.

Washington, DC 20585-1290

William.eckroade@hq.doe.gov 
Mr. Gustavo Vazquez, Environmental Engineer

Office of Office of Environmental Policy and Assistance, HS-22/FORS 1000 Independence Ave., S.W.

Washington, DC 20585

Gustavo.vazquez@eh.doe.gov

Ms. Amy Harris-Tehan

Training, Documents and Records

lowa State University

151 TASF

Ames, IA 50011-3400

ajotehan@ameslab.gov

Ms. Stacy Joiner, Coordinator

Intellectual Property and Technical Information

Ames Laboratory

332 TASF

Ames, IA 50011-3400

joiner@ameslab.gov

Mr. Gene Gunn, Chief

FFSESUPR

USEPA Region VII

901 North Fifth Street

Kansas City, KS 66101

Gunn.gene@epa.gov

Mr. Kris Goschen

Federal Facility Program Manager

USEPA Region VII

901 North $5^{\text {th }}$ Street

Kansas City, KS 66101

Goschen.kris@epa.gov

Mr. William A. Spratlin

Director, Air and Toxics Division

USEPA Region VII

901 North $5^{\text {th }}$ Street

Kansas City, KS 66101

Spratlin.william@epa.gov 
Ms. Melanie Rasmusson, MBA, Chief

lowa Department of Public Health

Bureau of Radiological Health

Lucas State Office Building

321 East $12^{\text {th }}$ Street

Des Moines, IA 50319-0075

Mrasmuss@idph.state.ia.us

Mr. Scott Vander Hart

DNR Environmental Services Administration

502 East 9th Street, Wallace Building

Des Moines, IA 50319-0034

Dr. David Inyang, Director

Environmental Health and Safety

1122 EHSSB

lowa State University

Ames, IA 50011-3660

Adinyan@iastate.edu

Senator Charles Grassley

United States Senate

Washington, DC 20510-0001

http://grassley.senate.gov/contact/contact.cfm

Senator Tom Harkin

United States Senate

Washington, D.C. 20510

http://harkin.senate.gov/contact/contact.cfm

Representative Tom Latham

United States House of Representatives

Washington, DC 20515

Tom.latham@mail.house.gov

Senator Herman Quirmbach

Senate Chambers

State House

Des Moines, IA 50319-0001

Herman.quirmbach@legis.state.ia.us

State Representative Beth Wessel-Kroeschell

State Capital

Des Moines, IA 50319

Beth.wessel-kroeschell@legis.state.ia.us 


\section{Ames Laboratory Community Advisory Group:}

Mr. Robert (Toby) Ewing

1411 Summit Avenue

Ames, IA 50010

Mr. Joe Lynch

3700 Onion Creek Lane

Ames, IA 50014

Stacy Joiner

1029 Florida Avenue

Ames, IA 50014-3069

\section{Ames Laboratory Management and Discipline Specialists:}

Director, Dr. Alex King

alexking@ameslab.gov

Deputy Director, Dr. Bruce Harmon

harmon@ameslab.gov

Chief Research Officer, Dr. Duane Johnson

ddj@ameslab.gov

Sponsored Research Administration, Debra Covey

covey@ameslab.gov

Chief Operations Officer, Mr. Mark Murphy

murphy@ameslab.gov

Information Officer, Mr. Steve Karsjen

karsjen@ameslab.gov

ESH\&A Manager, Mr. Tom Wessels

wessels@ameslab.gov

Radiation Safety Officer, Mr. Mike McGuigan

mcguigan@ameslab.gov

Industrial Hygiene, Mr. James Withers, $\mathrm{ClH}$

withers@ameslab.gov

Fire and Plant Protection, Mr. G.P. Jones

jonesgp@ameslab.gov

Industrial Safety, Mr. Shawn Nelson

nelsons@ameslab.gov 
Environmental Specialist, Mr. Dan Kayser kayser@ameslab.gov 


\section{APPENDIX A}

\section{Chemical Disposal Site (CDS) Correspondences}

1) Letter to IDPH requesting release of the CDS, September 30, 1998.

2) Letter from IDPH granting "unrestricted" release of the CDS, October 15, 1998.

3) Letter from IDPH to Edward J. Stanek, II, Ph.D., status of CDS, October 16, 1998.

4) Letter from ISU to DOE-Ames Group, October 22, 1998.

5) Letter from IDNR to ISU-EH\&S, groundwater monitoring status, October 8, 2008. 


\section{IOWA STATE UNIVERSITY \\ OF SCIENCE AND TECHNOLOGY}

September 30, 1998

Mr. Donald A. Flater

Chief, Bureau of Radiological Health

Iowa Department of Public Health

Lucas State Office Building

Des Moines, IA 50319-0075

Dear Mr. Flater:
Environmental Health and Safety

118 Agronomy Lab

Ames, lowa 50011-3200

515 294-5359

FAX 515 294-9357

Enclosed are 3 copies of the "Characterization Report for the Ames Laboratory Chemical Disposal Site - Iowa State University", dated September, 1998. This report reflects the latest work at the Chemical Disposal Site (CDS) which evolved from our meeting with IDPH on August 28, 1998. At that meeting we made the decision to remove any remaining surface soil radiation levels that were more than twice background. That work was accomplished and the affected areas were resurveyed on 9-1-98 to confirm that they were at background levels (IDPH personnel were present for the survey).

As a result of the above efforts, we believe the CDS site now meets the criteria for unrestricted release. Moreover, the Jones/McMahon study of groundwater movement at the CDS has been released, and confirms the assessment that the underground water plume has reached a steady state at the site. The down-gradient concentrations are expected to decrease over the coming years with the judgement that there is no potential threat to either Squaw Creek or the public water supply.

Therefore, after IDPH review of the enclosed report, lowa State University is requesting consideration of the following action:

1. Release of the CDS on an unrestricted basis.

2. Reduce the groundwater sampling frequency to once per year for the remainder of the 5 year schedule.

3. Allow closure of monitoring wells $\mathrm{MW}-9 \mathrm{~A}$ and $\mathrm{MW}-9 \mathrm{~B}$ because of their deteriorating condition. (This has already been verbally granted by $\mathrm{DPH}$ but we would appreciate having this in writing).

We appreciate the assistance and cooperation of the IDPH on the CDS project and look forward to a successful completion. We have enclosed enough copies of the "CDS Characterization Report" so you can provide them to the EPA offices involved in this project. When we hear back from the $\mathrm{DPH}$, we will provide appropriate copies to the Ames Lab, DOE and IDNR.

Sincerely,

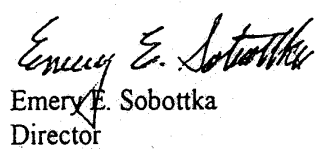

enclosure

cc Warren Madden

Paul Tanaka

H:IGROUPSIADMINICDS Characterization Report Letter September 30.doc 


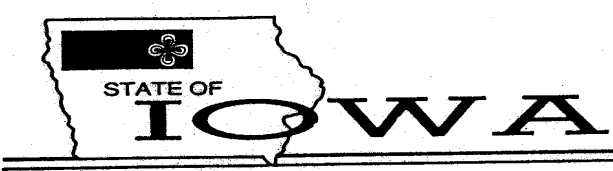

TERRY E. BRANSTAD, GOVERNOR

DEPARTMENT OF PUBLIC HEALTH

CHRISTOPHER G. ATCHISON, DIRECTOR

October 15, 1998

Emery Sobottka

Iowa State University

118 Agronomy Laboratory

Ames, Iowa 50011-3200

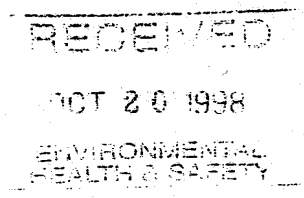

Dear Mr. Sobottka:

This correspondence refers to the "Characterization Report for the Ames Laboratory Chemical Disposal Site-Iowa State University:" You submitted that report to us under cover of your letter dated September 30, 1998.

We have read and reviewed the report and analyzed the data. We agree with your conclusions and recommendations.

The site, known as the Ames Laboratory Chemical Disposal Site, meets the standards for unrestricted use. Additionally, we concur with your recommendation that the groundwater sampling frequency be reduced to annual. This sampling will continue until 2002.

If you have any questions or comments, please call Dan McGhee or me at (515)2817007.

Sincerely,

O

bonald A. Flater, Chief

Bureau of Radiological Health

J:Vramlchemdisplfinal report resp.doc

LUCAS STATE OFFICE BUILDING / 321 E. 12 TH ST. / DES MOINES, IOWA $50319-0075$ DEAF RELAY (HEARING OR SPEECH IMPAIRED) 1-800-735-2942/INTERNET: HTTP://IDPH.STATE.1A.US/

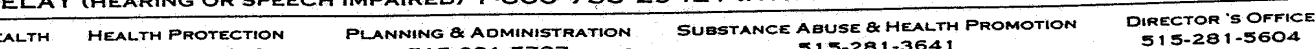

FAMILY \& COMM. HEALTH HEALTH PROTECTION PLANNINGQADMINISTRATION SUBSTANCEABUSE B HEALTH PROMOTION DIRECTOR'S OFFICE 


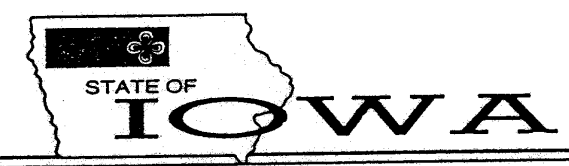

TERRY E BRANSTAD. GOVERNOR

October 16,1998

Edward J. Stanek, II, Ph.D.

2015 Grand Avenue

Des Moines, Iowa 50312

Dear Dr. Stanek:
DEPARTMENT OF PUBLIC HEALTH CHRISTOPHER G. ATCHISON, DIRECTOR

This correspondence refers to the chemical Disposal Site (CDS) in Ames, lowa. This area had been used as a disposal site by Ames Laboratory, a contractor for the U.S. Department of Energy (DOE). As you know, the DOE. remediated this site in 1994. They then published the results and made recommendations for the future use of the land.

The Iowa Code designates the Iowa Dept. of Public Health (IDPH) as the state's radiation control agency. Additionally, Iowa State University (ISU) holds an Iowa Radioactive Materials license. As a result, IDPH became involved, as an overseeing agency, with the CDS project in 1994.

In August 1996, and again in December 1997, IDPH went on record with DOE saying that it could neither agree with nor concur in the data or the recommendations as presented. Our stance was that a complete characterization of the CDS had not been conducted and that, therefore, the conclusions came from data that had no statistical relevance.

In the spring of 1997 ISU initiated a complete characterization study of the CDS. We have kept you apprised of the progress of that project.

On Friday, October 9, 1998, ISU submitted its final report. In that report, ISU concludes that the CDS meets the standards for unrestricted use and recommends that annual samples from the groundwater monitoring wells be continued, on an annual basis, until 2002 to confirm the results of the study. The U.S. Environmental Protection Agency accepts this monitoring regimen.

We have reviewed the ISU data and report. We agree with the conclusions and the recommendations. We have issued a letter to ISU stating that the CDS meets the standards for unrestricted use. That letter will also contain our concurrence to reduce the groundwater monitoring frequency to annually and to continue this monitoring until 2002.

LUSATATE OFFICE BUILING / 321 E 12 THST, DES MOINES. 1OWA 50319-0075 LUCAS STATE OFFICE BUILDING / 321 E. 12 TH ST. / DES MOINES. IOWA SO319-OOTS: 1 -800-735-2942/INTERNET: HTTP:/IDPTA.SA.US/

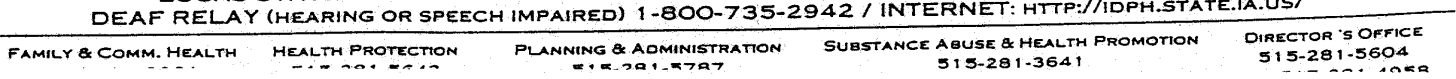


Page 2

Stanek, Edward

October 16, 1998

If you have any questions or comments, please do not hesitate to contact me.

Sincerely,

Smaed Gi Flater

Donald A. Flater, Chief

Bureau of Radiological Health

515-281-3478

515-242-6284-FAX

dflater@idph.state.ia.us

\section{$\mathrm{DAF} / \mathrm{r}$}

cc: Emery Sobottka, ISU

Joe Obr, IDNR

J:Lramichemdisplstanekefinal.doc 
IOWA STATE UNIVERSITY

OF SCIENCE AND TECHNOLOGY
Environmental Health and Safety 118 Agronomy Lab Ames, Iowa 50011-3200

515 294-5359

FAX 515 294-9357

October 22, 1998

Mr. James Buchar

Ames Group

Department of Energy

Chicago Operations Office

9800 South Cass Ave

Argonne, II 60439

Dear Mr. Buchar:

The additional sampling and testing that we have been conducting at the Ames Laboratory Chemical Disposal Site (CDS) has culminated in the Iowa Department of Public Health (IDPH) granting ISU unconditional release of the CDS site. In addition, the IDPH has also granted our request to reduce groundwater well water sampling frequency from one per quarter to once per year for the remainder of the sampling period (until year 2002). Enclosed are documents which describe CDS activities:

1. The final Characterization Report for the CDS.

2. A letter from ISU to IDPH (dated September 30, 1998) which requests unrestricted closure and reduces groundwater sampling frequency at the CDS.

3. Two letters from IDPH (dated October 15, 1998 and October 16, 1998) which grant ISU unrestricted release of the CDS and reduced groundwater sampling at the CDS until the year 2002 .

After you have had the opportunity to review these documents I would like to continue our discussion about coordinating a joint press release. A lot of people, departments, state and federal agencies, etc., have had a hand in completing this successful project and we may want to consider some recognition of that fact.

Sincerely,

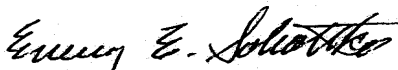

Emery). Sobottka

Director

enclosure

$\mathrm{cc}$

Tom Barton, Ames Lab

Tom Wessels, Ames Lab

Joe Obr, IDNR

Warren Madden (\#3 enclosure only)

Paul Tanaka (\#3 enclosure only) 
October 8, 2008

David Inyang

lowa State University

Environmental Heath and Safety

2809 Daley Drive

Ames, IA 50011-3660

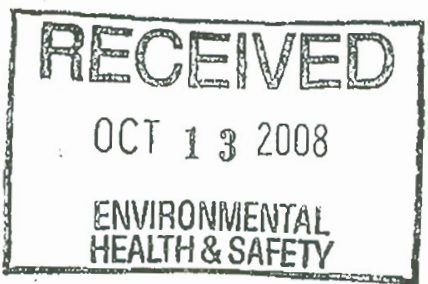

Dear Mr. Inyang,

This letter is to inform you that the IDNR has reviewed the site history and ground water monitoring results for the Ames Laboratory disposal site in the letter report of September 24, 2008 and supplemental monitoring data from 2002 through 2007 provided by Mr. Steve Simpson. The IDNR notes the request of ISU at this time to terminate ground water monitoring at the site and abandon the remaining monitoring wells. This recommendation is based on monitoring data that indicate the plume is stable and not migrating. In considering the request to terminate monitoring the IDNR contacted the lowa Department of Public Health to provide the opportunity to review the monitoring data from 2002-2007. The position of IDPH is that adequate data were already available when the site was closed in 1998 when it was approved for unrestricted use and that no new risk evaluation based on new data would be required (see enclosed email). Therefore, the IDNR with concurrence with IDPH agrees to the request for termination of ground water monitoring at the Ames Lab disposal site.

Please note that even though ground water monitoring is being terminated the site shall remain listed on the State Registry of Hazardous Waste Disposal Sites. Also, note the need for proper well abandonment procedures and submittal of completed well abandonment form 542-1226 (enclosed) or that can be found on the Contaminated Sites web site.

http://www.iowadnr.com/land/consites/conforms.html

Please contact me at 1-515-242-5087 if you have any questions.

Regards

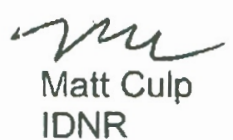

CC: Dan McGhee, IDPH Lucas State Office Building $321 \mathrm{E} 12^{\text {th }}$ Street Des Moines IA, 50319

IDNR Field Office Des Moines, lowa

Cal Lundberg, IDNR Contaminated Sites Section

502 EAST 9th STREET / DES MOINES, IOWA 50319-0034

PHONE 515-281-5918 FAX 515-281-6794 www.iowadnr.gov 


\section{APPENDIX B}

\section{Air Permit Correspondences}

1) U.S. Department of Energy Air Emissions Annual Report, Calendar Year 2010. 


\section{U.S. Department of Energy \\ Air Emissions Annual Report \\ Calendar Year 2010}

\section{SECTION I}

\section{Facility Information}

Site Name: Ames Laboratory, Iowa State University

Operations Office: Chicago Operations

Address: $\quad 9800$ South Cass Avenue

Argonne, IL 60439

Contact: Mike Saar Phone: 630-252-2245

Site Operator: Iowa State University

Site Address: G40 TASF, Iowa State University

Ames, IA 50011

Contact: Dan Kayser Phone: (515) 294-2153

\section{Site Description:}

The Ames Laboratory is located on the campus of Iowa State University (ISU) in Ames, Iowa. The Ames Laboratory is operated by ISU for the Department of Energy (DOE) under contract No. DE-AC02-07CH1 1358 in 2010. There are twelve buildings owned by the DOE. The Ames Laboratory conducts basic and intermediate applied research in physical, mathematical, and engineering sciences that underlie energy technologies and other areas of national importance. 


\section{SECTION II}

\section{Methods for Dose Assessment/Air Emissions Data}

Gram quantities of radionuclides were used in CY 2010. Radionuclides were used as reference standards in solutions or in solid form; consequently there were no radioactive air emissions and no exposures to the general public based on inventory usage and engineering controls.

\section{CERTIFICATION}

I certify under penalty of law that I have personally examined and am familiar with the information submitted herein and based on my inquiry of those individuals immediately responsible for obtaining the information, I believe that the submitted information is true, accurate and complete. I am aware that there are significant penalties for submitting false information including the possibility of fine and imprisonment. (See, 18 U.S.C. 1001).

Name: Dr. Alexander H. King

Title: Director, Ames Laboratory

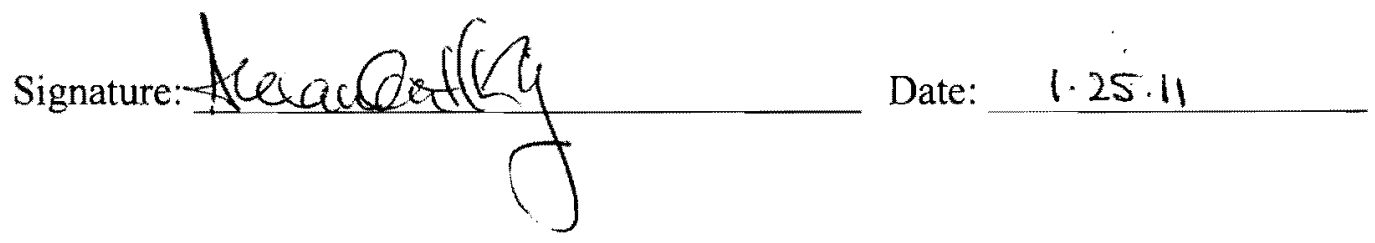




\section{APPENDIX C}

\section{Inactive Waste Sites Correspondences}

1) Letter from IDPH, Closure of nine waste sites, January 11, 1996.

2) Letter from DOE-CH, Regarding the lowa State College Dump Site, April 20, 1999.

3) Letter from IDPH, Closure of the Former lowa State College Dump Site, September 17, 2001.

4) Letter from IDPH, Closure of the Fire Service Institute Training Area, February 26, 2002. 


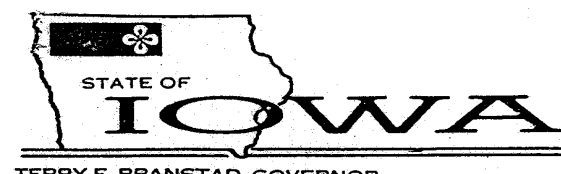

TERRY E. BRANSTAD, GOVERNOR

DEPARTMENT OF PUBLIC HEALTH CHRISTOPHER G. ATCHISON, DIRECTOR

January 11, 1996

Warren R. Madden

Vice President for Business and Finance

Iowa State University

125 Beardshear Hall

Ames, Iowa 50011-2038

Dear Mr. Madden:

Reference is made to your letter of January 5, 1996 in which you request our concurrence on the status of nine inactive waste sites which we possibly contaminated with radioactive materials as a result of the operation of Ames Laboratory as a DOE contractor in the past. Listed below are the sites by name and our conclusions as to the status of the site regarding closure.

1. Ames Old Waste Water Treatment Facility (WWTF): Met criteria for unrestricted use per Department letters to the city of Ames dated June 16, 1994 and February 17, 1995

2. Grand Avenue Under Pass: Based on the data provided by DOE, ISU and data collected by this Department this area meets the criteria for unrestricted use. In fact, there is information which indicates that this area never was subjected to the spreading of contaminated sludge from the WWTF.

3. Ames Municipal Cemetery: Based on the date provided by DOE, ISU and data collected by this Department this area meets the criteria for unrestricted use. In fact, there is information which indicates that this area never was subjected to the spreading of contaminated sludge from the WWTF.

4. Applied Science Center: Based on the data provided by DOE, ISU and data collected by this Department, this area meets the criteria for unrestricted use.

5. Block House Area : Based on the data provided by DOE, ISU and data collected by this Department, this area meets the criteria for unrestricted use.

6. Little Ankeny Debris Site: Based on the data provided by DOE, ISU and data collected by this Department, this area meets the criteria for unrestricted use.

7. Annex I: Based on the data provided by DOE, ISU and data collected by this Department, this area can be used as it is now, in perpetuity, without public health concerns. However, if the site is developed for any other purpose additional surveys or sampling will be necessary to confirm that if residual radioactive material exists it is not in amounts which could be of public health concern during the developmental process.

8. Annex $\Pi$ : : Based on the data provided by DOE, ISU and data collected by this Department, this area can be used as it is now, in perpetuity, without public health concerns. However, if the site is developed for any other purpose additional surveys or sampling will be necessary to confirm that if residual radioactive material exists it is not in amounts which could be of public health concern during the developmental process.

LUCAS STATE OFFICE BUILDING / DES MOINES. IOWA 50319-0075/515-281-5787 FAX \# (515) $281-4958$ / TDD-DEAF SERVICES \#(515) 242-6156 
Page 2

Madden, Warren $R$.

January 11, 1996

9. Ames Municipal Airport: Based on the data provided by DOE, ISU and data collected by this Department, this area can be used as it is now, in perpetuity, without public health concerns. However, if the site is developed for any other purpose additional surveys or sampling will be necessary to confirm that if residual radioactive material exists it is not in amounts which could be of public health concern during the developmental process.

Based on the above, it is my opinion that we concur with the University's decision to bring the nine sites to closure with the special provisions placed on Annex I, II and the Airport. I would like to take this opportunity to thank you, the ISU Staff and the Ames Laboratory Staff who have assisted in working through the long laborious process of reading the conclusions. We certainly look forward to working with all of you in the future. If you have question regarding the above, please do not hesitate to contact me.

\section{Sincerely,}

Trued l. Plate

Donald A. Flater, Chief

Bureau of Radiological Health

(515) 281-3478

cc:

E. Sobottka, ISU

Tom Newman, City of Ames

Dr. Tom Barton, Ames Laboratory

j:trad-adratmaddendoc 


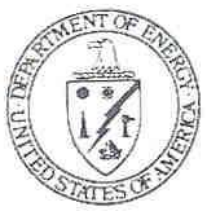

\section{Department of Energy \\ Chicago Operations Office \\ 9800 South Cass Avenue \\ Argonne, llinois 60439}

April 20, 1999

Dr. Aniefiok D. Inyang, Director

Environmental Health and Safety

118 Agronomy Laboratory

lowa State University

Ames, lowa 50011-3200

Dear Dr. Inyang:

\section{SUBJECT: IOWA STATE COLLEGE DUMP SITE}

References: 1. Letter, Taboas to Sobottka, dated January 30, 1996

2. Letter, Sobottka to Taboas, dated February 28, 1996

It has recently been brought to my attention that an old issue remains open relative to the lowa State's College Dump Site. As I can best determine the issue arose when the Department of Energy (DOE) in reviewing the University's “Review and Assessment of the Former lowa State College Dump Site" report provided some comments (Reference 1) for the University's consideration. As indicated in Reference 2, the University adopted most of the suggested changes. However, one statement as made regarding the availability of information about the disposal of beakers and containers at the site, which raised a concern with your predecessor. As can be seen from Reference 2, Mr. Sobottka was not aware of and did not have any evidence of anything other than uranium being disposed of at the site. Mr. Sobottka's letter requested that DOE make available any information we may have as to the origin or type of materials disposed of at the site and how we became aware of this information.

In trying to respond to this open issue, we have conducted a review internally of the statement previously made in our Reference 1 letter and we are not able to provide any documentation as requested. Our statement at the time was based on informal discussion with an Ames Laboratory employee (now retired) and a cursory review, over time, of some College Dump Site related documents, none of which were ever in our possession.

It is our position that without having any specific knowledge or records, other than as mentioned above, relative to the College Dump Site, we withdraw the comment in question and recommend that the report be finalized and the issue closed.

Enclosures:

Reference Letters

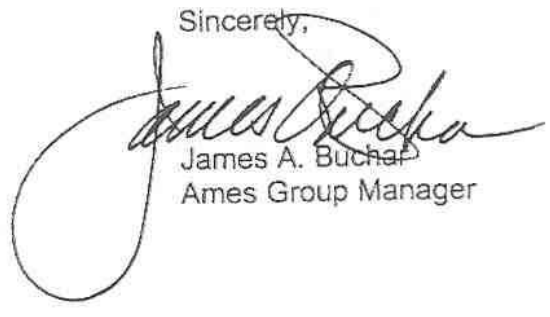

章 Fis

APR $2 \& \cdots$

ENVIRONMENTAL 


\section{STATE OF IOWA}

THOMAS J. VILSACK

GOVERNOR

SAILLY J. PEDERSON

L.T. GOVERNOR
DEPARTMENT OF PUBLIC HEALTH STEPHEN C. GLEASON. D.O., OIRECTOR

September 17, 2001

David Inyang, Ph.D., RSO

Iowa State University

118 Agronomy Lab.

Ames, Iowa 50011

Dear.Dr. Inyang:

This correspondence refers to your letter to me dated August 22, 2001. In that letter you enclosed a report entitled, "Review and Assessment of the Former Iowa State College Dump Site." This report detailed the actions taken to assess the radiological hazard at that site. Your letter requested that we review and comment on the report.

The report references and analyzes the results of soil sampling at the former dumpsite. We have reviewed this data and your conclusions. We agree that the data does show that the former lowa State College Dump Site meets the standards for unrestricted use.

We wish to remind you that our conclusions speak only to radiological standards and do not address heavy metals or organic compounds.

If you have any questions, please contact Dan McGhee at 515-725-0305 or me.

Sincerely,

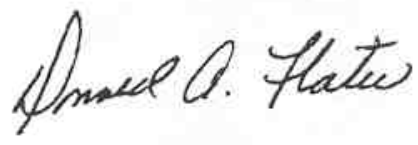

Donald A. Flater, Chief

Bureau of Radiological Health

(515) $281-3478$

401 SW 7 in STREET, SUITE D / DES MOINES, IOWA 50309-4611

DEAF RELAY (HEARING OR SPEECH IMPAIRED) 1-800-735-2942/ INTERNET: HTTP://IDPH.STATE.IA.US/

\begin{tabular}{ccc}
\hline DIRECTOR'S OFFICE & EXECUTIVE STAFF & DIV. OF AOMINISTRATION \& REGULATORY AFFAIRS \\
$515-281-5605$ & $515-281-5604$ & $515-281-5784$ \\
FAX/515-281-4958 & FAX $/ 515-281-4958$ & FAX $/ 515-281-4958$
\end{tabular}

DIV OF FAMILY \& COMMUNITY HEALTH DIV. OF HEALTH PROMOTION. PREVENTION \& AdOICTIVE BEHAVIORS 515-281-3931 
THOMAS J. VILSACK GOVERNOR

SALLY J. PEDERSON

LT. GOVERNOR

February 26, 2002

David Inyang, Ph.D.

Director, Environmental Health and Safety

Iowa State University

118 Agronomy Lab

Ames, Iowa 50011-3200

RE: Release of site for unrestricted use

Dear Dr. Inyang:

This correspondence refers to yjour letter, dated February 20, 2002, to me. In that letter you transmitted the "Final Status Survey Report for Fire Service Institute Training Area Iowa State University." You also requested "the site be released for unrestricted use."

We have reviewed the report and agree with your conclusion that the site meets the standards for unrestricted use. You may refer to these standards in the Iowa Administrative Code 641$40.29(136 \mathrm{C})$. We cannot, however, "release" this site because it was never restricted. We reiterate, though, that the data demonstrates compliance with unrestricted use.

If you have any questions, please contact Dan McGhee at 515-725-0305 or me.

Sincereiy,

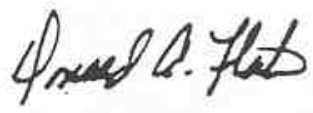

Donald A. Flater, Chief

Bureau of Radiological Health

515-281-3478

515-725-0318-FAX

dflater@idph.state.ia.us

$\mathrm{DAF} / \mathrm{rk}$

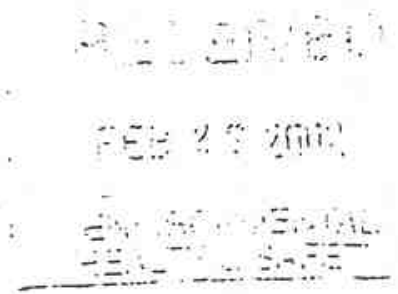

LUCAS STATE OFFICE BUILDING / $321 \mathrm{E}$. 12TH ST. / DES MOINES, 1OWA 50319-0075

DEAF RELAY (HEARING OR SPEECH IMPAIRED) 1-800-735-2942 / INTERNET: HTTP:I/WWW.IOPH.STATE.IA.US/

\section{DIRECTOR'S OFFICE \\ 515-281-5605}

FAX/515-281-4958
Div. OF COMMUNITY HEALTM

\$15-281-6535

515-281-5604

FAX/515-281-4958

FAXV515-242-6384
DIV. OF HEALTH PROTECTION \& ENVIRONMENTAL HEALTH

$515-281-7726$

FAX/515-281-4529

Div. OF TOBACCO USE PREVENTION \& CONTROL

$515-281-6225$

$\varepsilon_{A x / 515-281-6475}$ 


\section{APPENDIX D}

\section{EPA and DOE Correspondences}

1) DOE-AMSO memorandum approving Laboratory's EMS, June 29, 2009.

2) EPA letter (RCRA Inspection), April 27, 2006. 


\section{Department of Energy \\ Ames Site Office \\ 9800 South Cass Avenue \\ Argonne, Illinois 60439}

DATE: June 29, 2009

\section{SUBJECT: DECLARATION THAT AMES LABORATORY'S ENVIRONMENTAL MANAGEMENT SYSTEM IS "FULLY IMPLEMENTED"}

TO: $\quad$ George J. Malosh, Deputy Director for Field Operations, SC-3

By this memorandum I declare that the Environmental Management System (EMS) at Ames Laboratory is "fully implemented," consistent with the requirements of DOE O 450.1A, Environmental Protection Program. In particular:

(a) A formal audit of the EMS was conducted on April 6-9, 2009 by a qualified party outside the control or scope of the EMS per DOE O 450.1A, §4.1d(1)(a).

(b) The appropriate contractor senior management and DOE field office management have recognized and addressed the findings of the audit per DOE $\mathrm{O} 450.1 \mathrm{~A}, \S 4.1 \mathrm{~d}(1)(\mathrm{b})$. There were no major non-conformances identified in the validation audit. An approved corrective action plan is in place for the minor nonconformances identified in the audit.

(c) The senior contractor manager accountable for implementation of the EMS has declared conformance of the EMS to the requirements of paragraph 4.b of DOE $0450.1 \mathrm{~A}$.

On the basis of this declaration, and of my oversight of the contractor's EMS at this site, I declare that this EMS conforms to the requirements paragraph 4.b. of DOE O 450.1A.

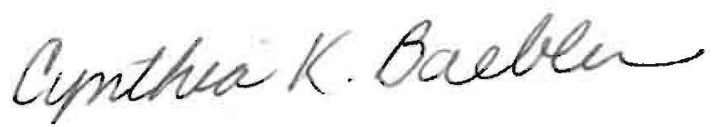

Cynthia K. Baebler, Manager

Ames Site Office

cc:

Thomas Traceski, HS-22

Steve Woodbury, HS-22

Marc Jones, SC-31

Sat Goel, SC-31.1

Dr. Alexander King, Director, Ames Laboratory

Mark Murphy, Ames Laboratory

Tom Wessels, Ames Laboratory, ESH\&A Manager 


\section{UNITED STATES ENVIRONMENTAL PROTECTION AGENCY \\ REGION VII \\ 901 NORTH 5TH STREET \\ KANSAS CITY, KANSAS 66101}

Tom Barton

19 JUN 2006

Director

Ames Laboratory \#3, DOE

G40 TASF Iowa State University

Ames, Iowa 50011

Dear Mr. Barton:

RE: Ames Laboratory \#3, DOE

Ames, Iowa

RCRA ID No. IA6890008950

On April 27, 2006, a representative of the U. S. Environmental Protection Agency (EPA) inspected your facility. The inspection was conducted under the authority of Section 3007 of the Resource Conservation and Recovery Act (RCRA). A copy of that inspection report is enclosed.

I have reviewed the inspection report and determined that no violations of RCRA were documented. Therefore, no further action concerning this matter is necessary at this time. Please note that EPA reserves its enforcement authorities, including assessment of penalties, for violations that occur at any time.

I would like to remind you that your facility is responsible for maintaining compliance with all applicable hazardous waste regulations. If there are any questions regarding this matter, please contact James Terry working under a grant at EPA at (913) 551-7958.

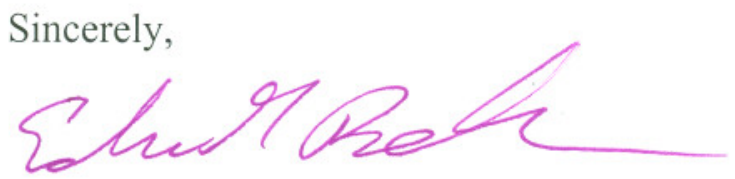

Edwin G. Buckner, P.E.

Compliance Officer

RCRA Enforcement and State Programs Branch

Enclosure

cc: Cal Lundberg

IDNR 